\title{
Effect of Long-Term Continuous Cotton Mono-Cropping on Depletion of Soil NPK and Changes in Some Selected Soil Chemical Characters on Vertisols and Fluvisols
}

\author{
Melese Menaleshoa $^{1, *}$, Ashenafi Worku', Wondimagegne Chekol ${ }^{2}$, Girma Tadesse ${ }^{3}$ \\ ${ }^{1}$ Ethiopian Institute of Agricultural Research, Addis Ababa, Ethiopia \\ ${ }^{2}$ St Mary University, Addis Ababa, Ethiopia \\ ${ }^{3}$ Collegesof Agricultural and Natural Resource Science, Debre Berhan University, Debre Berhan, Ethiopia \\ Email address: \\ melesemin@yahoo.com (M. Menaleshoa), ashuw21@gmail.com (A. Worku),wondichekol@yahoo.com (W. Chekol), \\ girma55@yahoo.com (G. Tadesse) \\ ${ }^{*}$ Corresponding author
}

\section{To cite this article:}

Melese Menaleshoa, Ashenafi Worku, Wondimagegne Chekol, Girma Tadesse. Effect of Long-Term Continuous Cotton Mono-Cropping on Depletion of Soil NPK and Changes in Some Selected Soil Chemical Characters on Vertisols and Fluvisols. Agriculture, Forestry and Fisheries. Vol. 5, No. 5, 2016, pp. 163-169. doi: 10.11648/j.aff.20160505.14

Received: June 5, 2016; Accepted: June 15, 2016; Published: September 6, 2016

\begin{abstract}
A long-term cotton exhaustion trial was conducted on lowland Vertisols and Fluvisols at Werer Agricultural Research Center during the 1968-2002 in Ethiopia to investigate nutrient depletion rate and changes in selected soil chemical properties. Treatments used include cultivated fallow, control, $80 \mathrm{kgN} \mathrm{ha}^{-1}, 80-80 \mathrm{kgNP}^{-1}, 80-80 \mathrm{kgNK} \mathrm{ha}^{-1}$ and $80-80-80 \mathrm{kgNPK}^{-1}$ arranged in RCBD with four and six replications in Vertisols and Fluvisols, respectively. The cotton was grown as a test crop and the status of soil N, P, K, OC, pHe and ECe were periodically monitored every seasons. Seed cotton yield had shown significant response to treatments imposed after 10 and 3 years of continuous cotton mono-cropping, respectively, on Vertisols and Fluvisols, and consistently continued for further 3 consecutive periodical checking years. Then onwards, until the end of the experiment, seed cotton yield didn't showed consistent yield response. Combined analysis revealed highly significant $(\mathrm{p}<0.01)$ yield response to $\mathrm{N}$ applications. Despite the long-term continuous mining of soil nutrients through seed cotton harvest and crop residue removal, soil analytical result revealed no indication of depletion in total nitrogen, available K and P. Soil pHe (in both soil types) and ECe only in Fluvisols tend show gradual increase.
\end{abstract}

Keywords: Nutrient, Cotton, Long-Term, Exhaustion, Vertisols, Fluvisols

\section{Introduction}

As a monocrop, cotton production, in the middle and lower Awash River basin, has been started late 1960's and continually been expanded by clearing more land this was previously under natural forest and grass ecology. The introduction of cultivation to virgin lands leads to change, often deleterious, affecting its ecological balance (Setter et al., 2004; Farifteh et al., 2006; Elgharably et al., 2010). Under irrigated agriculture, this is much pronounced particularly by negatively affecting the chemical, physical and biological properties of the soil (Rasool et al., 2007). The extent and rate of change, however, depends on inherent edaphic nature of the soil (parent fertility chemical behaviors, etc.), climatic condition and the level of management being practiced (Michael, 2012).

Excessive exhaustion of nutrients from the soil through continuous and mono cropping with little or no input only through residue incorporation or other external inputs obviously resulted in decline in soil productivity and negative nutrient balance (Wondimagegne and Abere, 2012). Therefore, it paves a way to look for a possible means that can help to predict the future trends so that corrective measures could be instituted in good time before some deleterious factors affect its potential productivity (Blaga et al., 1993; Muhammad, 2012). 
In addition, periodic investigation of soil nutrient is also required to monitor changes in soil physico-chemical properties so as to undertake corrective measures.

Cotton exhaustion trial was initiated at Werer research center some 34 and 28 years back on heavy clay soils (Vertisols) and light soil (Fluvisols) soils, respectively. The study aims to see the changes by inducing continuous cotton mono-cropping to force soil nutrient to deplete until the appearance of deficiency is appeared on the plant or indicated from soil and fertilizer tests so that corrective measures can be found as a guide to possible future requirements and a guard against a bad practice (Toor, 1990). Therefore, this paper is tried to find out after how many years of cotton continuous mono-cropping respond to fertilizer application and to investigate nutrient depletion rate and changes in soil chemical properties under Middle Awash climatic conditions.

\section{Materials and Methods}

\subsection{Characteristics of the Study Site}

The experiment was conducted at Werer Agricultural Research Center. Werer is located at $278 \mathrm{~km}$ to the east of Addis Ababa at an altitude of 740 masl and located at $9^{\circ} 12^{\prime} 8^{\prime \prime}$ to $9^{\circ} 27^{\prime} 46^{\prime \prime} \mathrm{N}$ latitude and $40^{\circ} 5^{\prime} 41^{\prime \prime}$ to $40^{\circ} 15^{\prime} 21^{\prime \prime}$ E longitude. The topography of the study area reflects the recent geomorphic history of the Middle Awash valley, through which deposits from the Awash River formed on extensive alluvial plain (EVDSA, 1989). Slope gradients are generally very low, and predominantly lying in the range between 1 and $2 \%$. The predominant soil types are Vertisols and Fluvisols having alluvial origin deposited from Awash River. The soil structure is generally weekly developed. Vertisols are silty clay to clay while Fluvisols are sandy loam to silty loam in texture (Heluf, 1985; Wondimagegne and Abere, 2012). Fluvisols are constituents of muscovite/illite clay minerals and Vertisols are dominated by montmorillonite clay minerals (Girma, 1999). The watering system adopted is virtually furrow irrigation. The mean annual rainfall is $571.3 \mathrm{~mm}$ and the mean minimum and maximum temperature are $19.6^{\circ} \mathrm{C}$ and $34.4^{\circ} \mathrm{C}$, respectively. The mean annual free water evaporation by the Class A pan and relative humidity recorded are $2803.7 \mathrm{~mm}$, and $50 \%$, respectively. The annual evapo-transpiration rate of the area exceeds that of annual precipitation.

\subsection{Biological Test for Evaluation of NPK Depletion}

The cotton plant was used as a test crop. Treatments including cultivated fallow, control, $80 \mathrm{kgN} \mathrm{ha}^{-1}, 80-80 \mathrm{kgNP}^{-1}$, $80-80 \mathrm{kgNK}^{-1}$ and $80-80-80 \mathrm{kgNPK}^{-1}$ arranged in randomized complete block design (RCBD) with four replications and six Vertisols and Fluvisols, respectively. Treatments were applied at two year interval until 1990 and one year interval from 1990 onwards. Urea, di-ammonium phosphate (DAP) and potassium chloride $(\mathrm{KCl})$ were used as a source of $\mathrm{N}, \mathrm{P}$ and $\mathrm{K}$, respectively. Cotton was planted during the main season. Urea was applied in split first half at planting and the remaining at flowering while the whole dose of DAP and $\mathrm{KCl}$ were applied at planting. Agronomic practices recommended in the area were followed. At maturity seed cotton yield was harvested and recorded.

\subsection{Soil Test}

Treatment-wise soil samples were collected during selected years of experimental period at a soil depth of 0-30 and 30$60 \mathrm{~cm}$ and analyzed for the different soil physico-chemical properties. Soil reaction $(\mathrm{pHe})$ and electrical conductivity (ECe) were determined from saturated paste extract following the methods described by FAO (1999) while Organic carbon was analyzed by wet oxidation with potassium dichromate $\left(\mathrm{K}_{2} \mathrm{Cr}_{2} \mathrm{O}_{7}\right)$ in a sulfuric acid medium (Walkley and Black, 1934). Then, percent organic matter content of the soils was estimated by multiplying the value of percent organic carbon by the conversion factor of 1.724 . Total $\mathrm{N}$ was analyzed using the Kjeldahl digestion, distillation and titration method as described by Blake (1965) by oxidizing the OM in concentrated sulfuric acid solution $\left(0.1 \mathrm{~N} \mathrm{H}_{2} \mathrm{SO}_{4}\right)$. Available phosphorus was determined calorimetrically using spectrophotometer after the extraction of the soil samples with $0.5 \mathrm{M}$ sodium bicarbonate $\left(\mathrm{NaHCO}_{3}\right)$ adjusted at $\mathrm{pH} 8.5$ following the Olsen extraction method as described by Olsen et al. (1954). Available potassium was measured by flame photometer from neutral normal ammonium acetate extraction (Knudsen et al., 1982).

\subsection{Statistical Analysis}

Analysis of variance (ANNOVA) for seed cotton yield data was carried out yearly using SAS software. And then a combined analysis over years, exclusively for nine years records of fertilizer treatment application years was also performed. Least significant difference (LSD) test was used in testing the means at $\mathrm{p}<0.05$ and 0.01 probability levels.

\section{Result and Discussion}

\subsection{Seed Cotton Yield Response to NPK Treatments}

Mean seed cotton yield values for the entire experimental durations of the long-term exhaustion trials are presented in Table 1 and 2 for Vertisols and Fluvisols, respectively. Significant yield response to NPK fertilizer treatments started after 10 and 3 years of continuous cotton mono-cropping on Vertisols (Table 1) and Fluvisols (Table 2) and consistently continued for additional 3 consecutive periodical checking years. Then onwards, it didn't showed consistent yield response to fertilizer treatments. Further no significant yield variation due to residual effect of treatments on both soil types. Similar results were reported by (Jeffrey et al., 2011).

Result from combined analysis over years revealed highly significant $(\mathrm{p}<0.01)$ treatment effect as shown in Table 3. Mean comparison for combined analysis showed that application of N, NP, NK, and NPK fertilizer treatments on 
both soil types gave equally superior mean seed cotton yield significantly higher than in control treatment (Table 4). It could be seen that therewas no any yield increment due to inclusion of either of $\mathrm{P}$ and $\mathrm{K}$ separately or both to $\mathrm{N}$ treatment than the sole effect of $\mathrm{N}$ application (Table 1, 2, and 4).

Table 1. Yearly mean seed cotton yield (Qt per ha) response to NPK fertilizer treatments on Vertisols.

\begin{tabular}{|c|c|c|c|c|c|c|c|}
\hline \multirow{2}{*}{ Year } & \multicolumn{4}{|c|}{ Mean seed cotton yield (Qt per ha) } & \multicolumn{3}{|c|}{ CV and LSD } \\
\hline & Control & $\mathbf{N}$ & NP & NK & NPK & CV (\%) & LSD (5\%) \\
\hline 1968 & 25.8 & 29.5 & 29.7 & 24.9 & 28.2 & 9 & NS \\
\hline 1969 & 24.0 & 23.6 & 25.1 & 21.6 & 23.4 & 8 & NS \\
\hline 1970 & 41.0 & 42.5 & 41.2 & 38.8 & 38.5 & 16 & NS \\
\hline 1971 & 41.4 & 39.8 & 39.6 & 43.2 & 36.6 & 8 & NS \\
\hline 1972 & 21.4 & 25.6 & 24.6 & 24.3 & 25.4 & 23 & NS \\
\hline 1974 & 37.1 & 38.6 & 36.4 & 39.5 & 39.8 & 15 & NS \\
\hline 1976 & 24.5 & 24.7 & 27.7 & 25.8 & 26.7 & 10 & NS \\
\hline 1978 & 27.5 & 34.8 & 33.7 & 33.6 & 33.5 & 14 & NS \\
\hline 1979 & 22.0 & 23.8 & 25.4 & 25.4 & 23.7 & 8 & NS \\
\hline 1980 & 35.9 & 41.0 & 41.1 & 37.5 & 38.0 & 17 & NS \\
\hline 1981 & $31.4^{\mathrm{b}}$ & $41.9^{\mathrm{a}}$ & $41.4^{\mathrm{a}}$ & $41.4^{\mathrm{a}}$ & $42.2^{\mathrm{a}}$ & 14 & 4.40 \\
\hline 1982 & 25.0 & 28.0 & 28.0 & 30.2 & 27.6 & 12 & NS \\
\hline 1983 & 16.1 & 18.9 & 15.9 & 18.2 & 19.6 & 7 & NS \\
\hline 1984 & $22.9^{\mathrm{b}}$ & $33.1^{\mathrm{a}}$ & $30.2^{\mathrm{a}}$ & $32.8^{\mathrm{a}}$ & $34.1^{\mathrm{a}}$ & 14 & 6.40 \\
\hline 1985 & 20.7 & 23.9 & 24.8 & 26.0 & 28.1 & 19 & NS \\
\hline 1986 & 24.2 & 24.4 & 24.3 & 25.3 & 27.8 & 10 & NS \\
\hline 1987 & $18.2^{\mathrm{b}}$ & $23.3^{\mathrm{a}}$ & $24.2^{\mathrm{a}}$ & $23.2^{\mathrm{a}}$ & $25.2^{\mathrm{a}}$ & 9 & 2.99 \\
\hline 1988 & 27.1 & 26.2 & 25.9 & 24.7 & 23.3 & 11 & NS \\
\hline 1989 & 12.7 & 13.4 & 12.3 & 13.3 & 11.7 & 11 & NS \\
\hline 1990 & 20.9 & 35.7 & 33.2 & 34.1 & 33.7 & 9 & NS \\
\hline 1991 & 30.8 & 33.5 & 34.5 & 32.1 & 35.2 & 8 & NS \\
\hline 1992 & 22.1 & 20.2 & 19.2 & 20.9 & 20.6 & 16 & NS \\
\hline 1993 & 16.6 & 19.1 & 21.1 & 16.5 & 19.9 & 23 & NS \\
\hline 1994 & 35.3 & 39.2 & 39.5 & 40.5 & 33.9 & 8 & NS \\
\hline 1995 & 22.8 & 24.3 & 28.8 & 26.9 & 41.8 & 16 & NS \\
\hline 1996 & 30.1 & 29.0 & 32.5 & 29.8 & 28.8 & 25 & NS \\
\hline 1997 & 12.9 & 14.2 & 12.1 & 11.4 & 12.3 & 29 & NS \\
\hline 1998 & 16.2 & 15.6 & 15.1 & 17.2 & 15.6 & 12 & NS \\
\hline 1999 & $\mathrm{Nd}$ & $\mathrm{Nd}$ & $\mathrm{Nd}$ & $\mathrm{Nd}$ & $\mathrm{Nd}$ & $\mathrm{Nd}$ & $\mathrm{Nd}$ \\
\hline 2000 & 30.5 & 30.5 & 35.3 & 34.3 & 39.0 & 11 & 3.75 \\
\hline 2001 & 16.9 & 21.7 & 24.9 & 24.3 & 21.6 & 11 & 4.19 \\
\hline 2002 & 15.3 & 14.8 & 17.8 & 14.2 & 15.9 & 12 & NS \\
\hline
\end{tabular}

* Means with the same letter in the same row are not significantly different, Figures in bold represent fertilizer application years. Nd: - no data (flood damage due to overflow of Awash River)

Result suggests that the major observed yield response could be accounted to the sole effect of $N$ fertilizer application. This could be due to higher atmospheric temperature that promotes loss of $\mathrm{N}$ by ammonia volatilization. This finding is supported by different reports (Wichern et al., 2006; Jackson and Vallaire, 2009; and Nacide et al., 2013). Absence of any yield advantage due to inclusion of $P$ and $K$ fertilizer as treatments may provide some evidence that experimental soil were of adequate level of these nutrients throughout experimental period (Table 6). Recent detailed characterization on status of available $K$ and $P$ of soils of the study area also revealed very high levels of these nutrients (Melese, 2006; Wondimagegne and Abere, 2012; Ashenafi, 2015). In general result clearly indicates that recently cotton has started to positively respond to $N$ fertilizer application.

Table 2. Yearly mean seed cotton yield (Qt per ha) response to NPK fertilizer treatments on Fluvisols.

\begin{tabular}{|c|c|c|c|c|c|c|c|}
\hline \multirow{2}{*}{ Year } & \multicolumn{5}{|c|}{ Mean seed cotton yield (Qt per ha) } & \multicolumn{2}{|c|}{ CV and LSD } \\
\hline & Control & $\mathbf{N}$ & NP & NK & NPK & CV (\%) & LSD (5\%) \\
\hline 1974 & 39.4 & 42.6 & 40.3 & 41.6 & 40.3 & 10 & NS \\
\hline 1976 & 20.8 & 24.3 & 19.9 & 25.1 & 21.4 & 14 & NS \\
\hline 1978 & 41.5 & 48.2 & 50.4 & 49.5 & 49.6 & 12 & NS \\
\hline 1979 & 39.4 & 36.9 & 37.6 & 36.6 & 38.4 & 12 & NS \\
\hline 1980 & 41.8 & 49.0 & 46.6 & 43.6 & 50.4 & 13 & NS \\
\hline 1981 & $35.8 \mathrm{~cd}$ & $46.1 \mathrm{a}$ & $41.0 \mathrm{abc}$ & 40.7abcd & $45.2 \mathrm{ab}$ & 13 & 5.70 \\
\hline 1982 & 36.8 & 39.2 & 36.0 & 44.2 & 40.4 & 14 & NS \\
\hline 1983 & 19.1 & 18.7 & 18.3 & 22.0 & 29.9 & 11 & NS \\
\hline 1984 & $30.5 b$ & $45.1 \mathrm{a}$ & $42.7 \mathrm{a}$ & $46.8 \mathrm{a}$ & $45.3 \mathrm{a}$ & 14 & 6.98 \\
\hline
\end{tabular}




\begin{tabular}{|c|c|c|c|c|c|c|c|}
\hline \multirow{2}{*}{ Year } & \multicolumn{4}{|c|}{ Mean seed cotton yield (Qt per ha) } & & \multicolumn{2}{|c|}{ CV and LSD } \\
\hline & Control & $\mathbf{N}$ & NP & NK & NPK & CV (\%) & LSD (5\%) \\
\hline 1985 & 28.2 & 32.5 & 31.6 & 31.6 & 29.6 & 12 & NS \\
\hline 1986 & 32.6 & 32.8 & 31.9 & 33.3 & 31.9 & 10 & NS \\
\hline 1987 & $15.3 b$ & $20.2 \mathrm{a}$ & $20.6 \mathrm{a}$ & $21.2 \mathrm{a}$ & $21.4 \mathrm{a}$ & 20 & 4.63 \\
\hline 1988 & 22.5 & 24.1 & 24.7 & 21.9 & 24.3 & 23 & NS \\
\hline 1989 & 15.93 & 18.7 & 18.1 & 17.7 & 17.9 & 20 & NS \\
\hline 1990 & $24.6 \mathrm{~cd}$ & $35.7 \mathrm{a}$ & $32.7 \mathrm{ab}$ & $29.2 b c$ & $26.8 \mathrm{bcd}$ & 20 & 7.04 \\
\hline 1991 & 35.1 & 37.7 & 38.2 & 38.6 & 34.5 & 18 & NS \\
\hline 1992 & 19.8 & 19.4 & 21.4 & 19.5 & 23.4 & 17 & NS \\
\hline 1993 & 12.1 & 12.7 & 15.5 & 17.5 & 14.2 & 30 & NS \\
\hline 1994 & 36.1 & 39.1 & 44.3 & 44.3 & 39.8 & 24 & NS \\
\hline 1995 & 36.2 & 33.9 & 35.0 & 35.0 & 35.1 & 27 & NS \\
\hline 1996 & 21.6 & 23.0 & 21.6 & 21.0 & 22.2 & 27 & NS \\
\hline 1997 & 21.0 & 24.3 & 20.6 & 19.9 & 23.7 & 18 & NS \\
\hline 1998 & 20.83 & 20.24 & 21.0 & 21.4 & 22.2 & 19 & NS \\
\hline 1999 & $\mathrm{Nd}$ & $\mathrm{Nd}$ & $\mathrm{Nd}$ & $\mathrm{Nd}$ & $\mathrm{Nd}$ & 18 & - \\
\hline 2000 & 30.8 & 28.8 & 28.7 & 27.4 & 28.7 & 26 & NS \\
\hline 2001 & 34.0 & 35.7 & 33.3 & 30.8 & 35.9 & 14 & NS \\
\hline 2002 & 31.0 & 26.1 & 33.6 & 33.5 & 32.5 & 25 & NS \\
\hline
\end{tabular}

* Means with the same letter in the same row are not significantly different, Figures in bold represent fertilizer application years, Nd: - no data (flood damage due to overflow of Awash River)

Table 3. Values of Analysis of variance over years on Vertisols and Fluvisols.

\begin{tabular}{lllll}
\hline \multirow{2}{*}{ Source } & \multicolumn{2}{l}{ Degree freedom } & Mean Square \\
\cline { 2 - 5 } & Vertisols & Fluvisols & Vertisols & Fluvisols \\
\hline Year & 8 & 8 & $1355.65821^{* *}$ & $3810.11451^{* *}$ \\
Replication & 3 & 5 & 7.57156 & 56.00808 \\
Treatment & 4 & 4 & $150.69274^{* *}$ & $280.36916^{* *}$ \\
Total & 15 & 17 & & \\
\hline
\end{tabular}

In some instance absence of depletion in soil $\mathrm{P}$ and $\mathrm{K}$ status throughout long-term continuous cropping might be attributed to the presence of seasonal additions of potash and phosphoric rich sediments through Awash River deposition during the course of irrigation practices.

Table 4. Over years (9 years) mean seed cotton yield response to NPK treatments.

\begin{tabular}{|c|c|c|}
\hline \multirow{2}{*}{ Treatment } & \multicolumn{2}{|c|}{ Mean seed cotton yield (q/ha) } \\
\hline & Vertisols & Fluvisols \\
\hline Control & $24.46^{\mathrm{b}}$ & $28.13^{\mathrm{b}}$ \\
\hline $80 \mathrm{kgN} \mathrm{ha}^{-1}$ & $28.77^{\mathrm{a}}$ & $33.01^{\mathrm{a}}$ \\
\hline $80-80 \mathrm{kgNP} \mathrm{ha}^{-1}$ & $28.93^{\mathrm{a}}$ & $32.89^{\mathrm{a}}$ \\
\hline 80-80-80kgNPK ha-1 & $28.96^{\mathrm{a}}$ & $33.87^{\mathrm{a}}$ \\
\hline $80-80 \mathrm{~kg} \mathrm{NK} \mathrm{ha-1}$ & $29.38^{\mathrm{a}}$ & $32.74^{\mathrm{a}}$ \\
\hline CV $(\%)$ & 15 & 18 \\
\hline $\mathrm{SE}( \pm)$ & 4.19 & 5.81 \\
\hline $\operatorname{LSD}(0.01)$ & 1.90 & 2.20 \\
\hline
\end{tabular}

* Means with the same letter within column are not significantly different

With regard to yield trend, the result indicates that there was no clear and defined trend showing very high variability of results between years (Table 1 and 2). However, highly significant yield a variation has been observed between years could be accounted to the variability impact of rainfall, radiation and temperature variations between years (Table 3).

\subsection{Soil Physico-Chemical Properties}

\section{Soil Reaction (pHe) and Salinity (ECe)}

Analytical result of soil $\mathrm{pHe}$ and ECe characteristics for soil samples of selected years is given in Table 5. As the table depicts, pHe values within the same year didn't showed any remarkable variation due to treatment effects. Generally, on Vertisols, the $\mathrm{pHe}$ value of surface soil layer $(0-30 \mathrm{~cm})$ varied between 7.7-7.9, 7.8-7.9, and 8.6-8.8, respectively during 1977, 1999 , and 2003 , while sub-surface soil layer $(30-60 \mathrm{~cm})$ varied from 7.7-7.8, 7.8-8.0, and 8.5-8.8 in respective testing years. On Fluvisols surface soil contained $\mathrm{pHe}$ varied from 7.7-7.9, 7.6-7.9, and 8.2-8.5 and from 7.8-8.0, 7.6-7.8, and 8.3-8.5 on sub-surface soil sample in respective years of investigation.

Generally, the result indicated that substantial increase in pHe from slightly alkaline to moderately alkaline level was noticed after 34 and 28 years of the experimental period on Vertisols and Fluvisols, respectively. Survey reports also indicated that ground water table increased year after year beginning the development of large-scale irrigated farms in the area (AIP, 1982). Increase in pHe over years could be ascribed to an increase in sodium rich groundwater table as has been also evidenced from common occurrence of such events in the irrigated farms of the area. The result of this study was in agreement with those reported by different authors (FAO, 1988; Ghafoor et al., 2004). According to FAO (1983), at present pHe level of soils of the experimental field and soils of state and private owned farms of the Amibara area as well has getting alkaline and may affect crop yield through affecting solubility and, hence, availability of certain nutrients.

Similar to $\mathrm{pHe}$, treatments within individual years didn't varied significantly and also didn't showed any noticeable trend of change over years in ECe values. ECe value of soil samples from all treatments of all years in Vertisols appeared low and very low for Fluvisols (1977) that could be rated as non-saline (FAO, 1988; Ashenafi, 2015). However, ECe values for soil samples during 1999 (25 years after the beginning of the experiment) exhibited higher values ranging between slightly saline to strongly saline class of salinity, which eventually 
declined to the extent of non-saline to slightly saline class during 2003.

Table 5. Soil pHe and ECe characteristics as influenced by long-term continuous cotton mono-cropping.

\begin{tabular}{|c|c|c|c|c|c|c|c|c|c|c|c|c|c|}
\hline \multirow{3}{*}{ Treatment } & \multirow{3}{*}{$\begin{array}{l}\text { Soil } \\
\text { Depth } \\
\text { (Cm) }\end{array}$} & \multicolumn{6}{|l|}{ pHe } & \multicolumn{6}{|c|}{ ECe $(d S / m)$} \\
\hline & & \multicolumn{3}{|c|}{ Fluvisols } & \multicolumn{3}{|c|}{ Vertisols } & \multicolumn{3}{|c|}{ Fluvisols } & \multicolumn{3}{|c|}{ Vertisols } \\
\hline & & 1977 & 1999 & 2003 & 1977 & 1999 & 2003 & 1977 & 1999 & 2003 & 1977 & 1999 & 2003 \\
\hline \multirow{2}{*}{ Fallow } & $0-30$ & 7.7 & 7.6 & 8.5 & 7.7 & 7.9 & 8.7 & 0.76 & 9.51 & 1.57 & 0.82 & 0.39 & 0.27 \\
\hline & $30-60$ & 7.8 & 7.7 & 8.3 & 7.7 & 7.9 & 8.5 & 0.94 & 3.86 & 5.92 & 0.90 & 0.32 & 0.23 \\
\hline \multirow{2}{*}{ Control } & $0-30$ & 7.8 & 7.6 & 8.5 & 7.7 & 7.8 & 8.7 & 0.75 & 7.54 & 1.87 & 0.90 & 0.39 & 0.24 \\
\hline & $30-60$ & 7.8 & 7.7 & 8.5 & 7.8 & 7.9 & 8.7 & 0.86 & 4.87 & 1.18 & 0.66 & 0.33 & 0.20 \\
\hline \multirow{2}{*}{$\mathrm{N}$} & $0-30$ & 7.8 & 8.0 & 8.4 & 7.8 & 7.8 & 8.7 & 1.30 & 4.77 & 1.68 & 0.74 & 0.35 & 0.20 \\
\hline & $30-60$ & 7.9 & 7.9 & 8.2 & 7.8 & 7.9 & 8.8 & 0.72 & 2.46 & 5.30 & 0.73 & 0.34 & 0.19 \\
\hline \multirow{2}{*}{ NP } & $0-30$ & 7.8 & 7.8 & 8.5 & 7.7 & 7.8 & 8.8 & 0.89 & 4.37 & 1.80 & 0.70 & 0.39 & 0.19 \\
\hline & $30-60$ & 8.0 & 7.8 & 8.5 & 7.8 & 8.0 & 8.8 & 0.89 & 3.00 & 2.06 & 1.00 & 0.37 & 0.17 \\
\hline \multirow{2}{*}{ NK } & $0-30$ & 7.8 & 7.8 & 8.5 & 7.8 & 7.9 & 8.6 & 0.71 & 7.78 & 1.72 & 1.10 & 0.38 & 0.20 \\
\hline & $30-60$ & 7.9 & 7.8 & 8.4 & 7.8 & 7.9 & 8.7 & 0.98 & 5.20 & 2.62 & 1.05 & 0.33 & 0.22 \\
\hline \multirow{2}{*}{ NPK } & $0-30$ & 7.9 & 7.6 & 8.5 & 7.8 & 7.9 & 8.7 & 0.75 & 10.26 & 1.80 & 0.80 & 0.34 & 0.22 \\
\hline & $30-60$ & 7.8 & 7.7 & 8.4 & 7.8 & 7.8 & 8.6 & 0.77 & 8.76 & 3.40 & 0.84 & 0.29 & 0.22 \\
\hline
\end{tabular}

Remark: - Soil sample for 1999 was collected three months after massive flooding due to over flow of Awash River was drained

As can be clearly seen from the Table 5 salinity level of surface soils constantly contained higher values than the subsurface soil. Such trend of salinity distribution in the soil profile is an indication of upward movement of salt through capillary and/or evaporation. It could be suggested that flooding incident due to overflow of Awash River in 1999 might be contributed to the recharge of saline ground water table there by contributing to such an increase in ECe values in the same year. Similarly result obtained by Frew (2012) from piezometers for ground water monitoring installed Amibara water project area.

\subsection{OM, Total N, Available Pand K Status}

Soil organic matter content of Vertisols and Fluvisols for selected years of the experimental period is depicted in Table 6 . The table has shown that fallowing, control and other treatments within individual soil testing years didn't resulted in any noticeable variation in soil organic matter content. On the other hand, irrespective of treatments organic matter content had showed an increasing trend over years particularly in Vertisols. In general, organic matter content of both soil types was low which is common in mineral soils. This could be due to the study area was hot climate the oxidation of organic residues was very high that indicate for redaction of organic matter content in the soil. Similarly result obtained by Ashenafi (2015) at the study area.

Table 6 and 7 presents' soil analytical results were for total $\mathrm{N}$, available $\mathrm{P}$ and $\mathrm{K}$ status as affected by long-term continuous mono-cropping of cotton on both soil types. On both soil types level of total nitrogen during all selected sample testing years didn't showed any notable variation due to continuous cropping and fallowing treatments. Surface soil layer always exhibited higher value of total nitrogen than the sub-surface. The result presented in this study agreed with the report of Yacob (2015). Despite continuous mining of soil $\mathrm{N}$ through seed cotton harvest and crop residue removal, recent (2003) soil test values for fallow, control and $\mathrm{N}$ receiving plots (during periodical checking period) revealed that there was no defined indication of depletion in soil total nitrogen status compared to results in the early period of experimental duration (1977). According to the rating of Tekalign (1991), status of soil total nitrogen in both soils was found to be low. Even though total nitrogen often used as a general guide for the evaluation of parent fertility of soil with respect to this nutrient it must be noted, however, that total nitrogen status of a soil is a poor indicator of its availability for immediate crops.

Table 6. Organic matter and total nitrogen content as influenced by long-term cultivation.

\begin{tabular}{|c|c|c|c|c|c|c|c|c|c|c|c|c|c|}
\hline \multirow{3}{*}{ Treatment } & \multirow{3}{*}{$\begin{array}{l}\text { Depth } \\
\text { (cm) }\end{array}$} & \multicolumn{6}{|c|}{ Vertisols } & \multicolumn{6}{|c|}{ Fluvisols } \\
\hline & & \multicolumn{3}{|c|}{ OM (\%) } & \multicolumn{3}{|c|}{ Total N (\%) } & \multicolumn{2}{|c|}{ OM (\%) } & \multicolumn{4}{|c|}{ Total N (\%) } \\
\hline & & 1977 & 1999 & 2003 & 1977 & 1999 & 2003 & 1977 & 1999 & 2003 & 1977 & 1999 & 2003 \\
\hline \multirow{2}{*}{ Fallow } & $0-30$ & 1.95 & 1.51 & 2.44 & 0.10 & 0.07 & 0.07 & 0.82 & 1.57 & 2.82 & 0.06 & 0.04 & 0.07 \\
\hline & $30-60$ & 1.14 & 1.29 & 1.84 & 0.06 & 0.06 & 0.06 & 0.39 & 0.56 & 2.31 & 0.03 & 0.03 & 0.07 \\
\hline \multirow{2}{*}{ Control } & $0-30$ & 1.52 & 1.19 & 2.17 & 0.08 & 0.06 & 0.06 & 0.8 & 1.28 & 1.81 & 0.07 & 0.07 & 0.09 \\
\hline & $30-60$ & 1.10 & 1.62 & 2.10 & 0.06 & 0.06 & 0.05 & 0.41 & 0.74 & 2.77 & 0.03 & 0.04 & 0.07 \\
\hline \multirow{2}{*}{$\mathrm{N}$} & $0-30$ & 1.55 & 1.7 & 2.17 & 0.07 & 0.07 & 0.06 & 0.84 & 1.46 & 2.98 & 0.06 & 0.06 & 0.07 \\
\hline & $30-60$ & 0.74 & 1.05 & 1.87 & 0.04 & 0.06 & 0.07 & 0.49 & 0.63 & 3.22 & 0.03 & 0.08 & 0.08 \\
\hline \multirow{2}{*}{ NP } & $0-30$ & 1.65 & 1.45 & 2.31 & 0.08 & 0.07 & 0.06 & 0.55 & 0.8 & 2.98 & 0.06 & 0.06 & 0.07 \\
\hline & $30-60$ & 0.91 & 1.07 & 2.06 & 0.04 & 0.06 & 0.06 & 0.51 & 0.61 & 2.55 & 0.03 & 0.05 & 0.06 \\
\hline \multirow{2}{*}{ NK } & $0-30$ & 1.77 & 1.31 & 2.17 & 0.11 & 0.07 & 0.04 & 0.82 & 0.7 & 2.77 & 0.06 & 0.06 & 0.07 \\
\hline & $30-60$ & 0.98 & 0.62 & 1.67 & 0.06 & 0.05 & 0.04 & 0.39 & 0.38 & 2.74 & 0.04 & 0.03 & 0.07 \\
\hline \multirow{2}{*}{ NPK } & $0-30$ & 1.98 & 1.02 & 2.3 & 0.09 & 0.06 & 0.05 & 0.81 & 0.84 & 2.51 & 0.06 & 0.06 & 0.06 \\
\hline & $30-60$ & 1.38 & 0.95 & 2.00 & 0.06 & 0.04 & 0.05 & 0.43 & 0.68 & 2.16 & 0.03 & 0.05 & 0.05 \\
\hline
\end{tabular}


Similar to total nitrogen, the level of available phosphorous had not showed any remarkable variations due to treatments within individual years. Irrespective of treatments, however, there was substantial build up in available P over years when comparing the values of $\mathrm{P}$ during 1977 with that during 1999 and 2003 in both soils For instance in Fluvisols contained mean value 6 ppm phosphorous during 1977 but had increased to 31 ppm in 1999. Similar trends were observed in Vertisols (Table 7). No adequate explanation could be drawn to such considerable buildup of $\mathrm{P}$ within short period of time except that $\mathrm{P}$ might had been deposited from sediment rich flood incident due to the over flow of Awash River in 1999. Result indicated that currently both soil types contained more than adequate level of $P$ for plant requirement. In general, the higher contents of available P observed in the soil of the studied area was in agreement with the results reported by many authors (Tekalign and Haque, 1991; Wondimagegne and Abere, 2012). This may suggests that absence of response to $\mathrm{P}$ fertilizer application throughout the testing periods could be due to high soil P status of the experimental soils.

Table 7. Available phosphorous and potassium status of soil as influenced by long-term continuous cotton mono-cropping.

\begin{tabular}{|c|c|c|c|c|c|c|c|c|c|c|c|}
\hline \multirow{3}{*}{ Treatment } & \multirow{3}{*}{ Depth (cm) } & \multicolumn{6}{|c|}{ Avail. P (ppm) } & \multicolumn{4}{|c|}{ Avail. K (Cmolc $\left.{ }_{(+)} \mathrm{kg}^{-1}\right)$} \\
\hline & & \multicolumn{3}{|c|}{ Vertisols } & \multicolumn{3}{|c|}{ Fluvisols } & \multicolumn{2}{|c|}{ Vertisols } & \multicolumn{2}{|c|}{ Fluvisols } \\
\hline & & 1977 & 1999 & 2003 & 1977 & 1999 & 2003 & 1977 & 1999 & 1977 & 1999 \\
\hline \multirow{2}{*}{ Fallow } & $0-30$ & 10 & 45 & 53 & 6 & 31 & 30 & 3.08 & 2.59 & 1.95 & 1.54 \\
\hline & $30-60$ & 5 & 43 & 49 & 3 & 32 & 40 & 1.74 & 2.50 & 0.64 & 0.71 \\
\hline \multirow{2}{*}{ Control } & $0-30$ & 10 & 45 & 73 & 5 & 29 & 27 & 3.40 & 2.60 & 2.12 & 1.80 \\
\hline & $30-60$ & 3 & 47 & 53 & 2 & 30 & 30 & 1.34 & 2.62 & 0.64 & 1.19 \\
\hline \multirow{2}{*}{$\mathrm{N}$} & $0-30$ & 2 & 38 & 68 & 3 & 29 & 30 & 3.03 & 2.53 & 2.44 & 2.02 \\
\hline & $30-60$ & 3 & 36 & 54 & 3 & 28 & 50 & 1.03 & 2.32 & 0.77 & 1.59 \\
\hline \multirow{2}{*}{ NP } & $0-30$ & 4 & 35 & 41 & 10 & 30 & 28 & 2.84 & 2.65 & 2.31 & 1.99 \\
\hline & $30-60$ & 6 & 21 & 31 & 2 & 29 & 30 & 0.96 & 2.40 & 0.95 & 1.58 \\
\hline \multirow{2}{*}{ NK } & $0-30$ & 3 & 38 & 44 & 7 & 33 & 27 & 3.24 & 2.70 & 1.31 & 1.72 \\
\hline & $30-60$ & 6 & 44 & 36 & 2 & 34 & 33 & 1.96 & 2.05 & 0.62 & 1.38 \\
\hline \multirow{2}{*}{ NPK } & $0-30$ & 4 & 40 & 35 & 3 & 38 & 32 & 2.54 & 2.60 & 2.20 & 2.02 \\
\hline & $30-60$ & 23 & 36 & 36 & 4 & 28 & 57 & 1.20 & 2.73 & 0.64 & 1.55 \\
\hline
\end{tabular}

Table 7 indicated that soil $\mathrm{K}$ content within individual experimental year didn't showed variation due to cropping fallowing or fertilizer $\mathrm{K}$ applications. Regarding its status no clearly defined trend of either increasing or decreasing trend of change was detected. In general, the level of available $\mathrm{K}$ on both soil types appeared to be more than adequate of cotton $\mathrm{K}$ requirement. In general, the higher contents of available $\mathrm{K}$ observed in the soils of the study area is in agreement with the result reported by (Girma, 1999; Melese, 2006).

Recent detailed study on soil potassium forms and foliar $\mathrm{K}$ status of cotton had also indicated that readily available as well as the reserve forms of $\mathrm{K}$ in both soils of the area throughout the soil layers appeared well above the critical limits. Foliar potassium status of cotton was also reported to be within the range of sufficiency level, further, reflecting adequate supplying capacity of this nutrient in these soils. Non-prevalent response of seed cotton to $\mathrm{K}$ fertilizer treatments could be ascribed to high level of inherent soil $\mathrm{K}$ status of soils of the experimental field.

\section{Conclusion}

Result of long-term exhaustion trial indicated that the absence of depletion in soil available phosphorous and potassium while there was continuous removal of these nutrients through seed cotton harvest and removal of crop residues inferring that experimental soils had inherent high level of these nutrients. It must be noted, however, that $\mathrm{P}$ and $\mathrm{K}$ bearing minerals do not provide an inexhaustible $\mathrm{P}$ and $\mathrm{K}$ source, and with time, the rate of release from the reserve source may decline. Thus, periodic checking of $\mathrm{P}$ and $\mathrm{K}$ supplying status of these soils is required. In addition, further research is required regarding the annual input/output balance of these nutrients to formulate sound $\mathrm{P}$ and $\mathrm{K}$ management strategies in long-term basis.

Even though total nitrogen depletion was not detected from soil test results, observed seed cotton yield response to sole application of $\mathrm{N}$ fertilizer with the advance in continuous cotton cropping could be an indication of gradual depletion in available form of soil nitrogen. As significant seed cotton yield response has been already detected from the long-term exhaustion trial further research on the optimum rate and time of application of nitrogen fertilizer, particularly on old farms of the target area (Amibara irrigated cotton farms) is required to be conducted on both soil types. Further, progressive changes in soil $\mathrm{pHe}$ and ECe characteristics observed with the advance in continuous cropping of the exhaustion trial indicates that soils of the area are potentially salt affected suggesting a need for proper management practices be instituted to halt secondary salinization and sodiciation.

\section{References}

[1] AIP (Amibara Irrigation Project II) (1982). Drainage and salinity study recommendations for field drainage. Vol. 1. Study and Recommendations. Sir William Halcrow and Partners. 
[2] Ashenafi Worku (2015). Assessment and Mapping of Fertility Status of Salt Affected soils Amibara Area, Central Rift Valley of Ethiopia. MSc Thesis, School of Graduate Studies, Haramaya University. Haramaya, Ethiopia

[3] Blaga, G., Dumitro, V., Bunescu, C., Rauta, T., Pacurar I. and Oroian E. (1993). The influence of organic, mineral-organic and mineral fertilizer applications on the yields of maize and oat grown in sterile waste soils from capus surface mine. Buletinul University Stiinte Cluj Napoca serial Agricultural in Horticultural, 47 (2): 103-109 (CAB Absts. 1998-99/07).

[4] Blake, C. A. (1965). Methods of soil analysis. Part I, American Society of Agronomy. Madison, Wisconsin, USA

[5] Elgharably, A., Marschner, P. and Rengasamy P. (2010). Wheat growth in a saline sandy loam soil as affected by $\mathrm{N}$ form and application rate. Journal of Plant and Soil, 328: 303-312.

[6] EVDSA (Ethiopian Valley Development Studies Authority) (1989). Master plan for the development of surface water recourse in the Awash basin. Final report, Vol. 7, Ministry of Water Resource

[7] FAO (Food and Agriculture Organization) (1983). Guidelines: Land evaluation for rain fed agriculture. FAO Soils Bulletin 52, Rome, Italy.

[8] FAO (Food and Agriculture Organization) (1988). Salt Affected Soils and Their Management. Soil Resources, Management and Conservation Service FAO Land and Water Development Division, FAO Soils Bulletin 39, Rome, Italy.

[9] FAO (Food and Agriculture Organization) (1999). Soil Salinity Assessment: Methods and Interpretation of Electrical Conductivity Measurements, FAO Irrigation and Drainage Paper 57, Rome, Italy.

[10] Farifteh, J., Farshad, A. and George, R. J. (2006). Assessing saltaffected soils using remote sensing, solute modeling and Geophysics. Geoderma, 30 (2): 191-206

[11] Frew Abebe (2012). Appraisal and mapping of soil salinity problems in Amibara area of middle awash basin. MSc Thesis, School of Graduate Studies, Haramaya University. Haramaya, Ethiopia.

[12] Ghafoor, A., Qadir M. and Murtaza G. (2004). Salt-Affected Soils: Principles of Management, Allied Book Centre, Urdu Bazar, Lahore, Pakistan.

[13] Girma Tadesse (1999). Potassium supplying capacity of Middle Awash soils. Ethiopian Journal Natural Resource. 1:1. Addis Ababa

[14] Heluf G/Kidan (1985). Investigation on salt affected soils and irrigation water quality in Middle Awash Amibara plain, Rift valley zone of Ethiopia. M. Sc. Thesis AUA, Alemaya, Ethiopia.

[15] Jackson, C. R. and Vallaire, S. C. (2009). Effects of salinity and nutrients on microbial assemblages in Louisiana wetland sediments. Journal of Wetlands Soil, 29 (1): 277- 287

[16] Jeffrey V., Marc O. and Gaspard V. (2011). Enhancing Sustainability of Cotton Production Systems in West Africa: A Summary of Empirical Evidence from Burkina Faso. Journal Sustainability 1 (3): 1136-1169.

[17] Knudsen, D., Peterson, G. A. and Pratt, P. F. (1982). Potassium. In: A. L. Page (Ed.) Methods of soil analysis. Chemical and microbiological properties. America Society of Agronomy, and Soil Science of America, Inc. Madison, Wisconsin, USA. 229230 .

[18] Melese Menaleshoa (2006). Vertical distribution of forms, release dynamics and its availability for cotton plant in major soil types of Amibara irrigated cotton farms in Ethiopia. MSc Thesis, School of Graduate Studies Hawassa University. Hawassa, Ethiopia.

[19] Michael, E. (2012). Factors Affecting Soil Development, Soil Systems, and the Physical Environment: an Introduction to Physical Geography, University of Wisconsin.

[20] Muhammad Waseem, 2012. Integrated nitrogen management in hybrid maize (Zea mays L.). PhD dissertation, Faculty of Agriculture University of Agriculture, Faisalabad, Pakistan.

[21] Nacide, K., Sagliker, H. and Cengiz, D. (2013). Nitrogen mineralization in some saline soils at Eastern Mediterranean coasts, Turkey, Eurasian Journal of Biosciences, 7: 95-100.

[22] Olsen, S. R., Cole, C. V., Watanable F. S. and Dean, L. A (1954) Estimation of variable phosphorus in soil by extraction with sodium bicarbonate. USDA Circular. 939: 1-19.

[23] Rasool R., Kukal, SS. and Hira, GS. (2007). Soil physical fertility and crop performance as affected by long term application of FYM and inorganic fertilizers in rice-wheat system. Journal of Soil and Tillage Research, 96 (1-2): 64-72.

[24] Setter, TL., Waters, I., Khabaz-Saberi, H., Mc Donald, G. and Biddulph, B. (2004). Screening for water logging tolerance of crop plants. pp. 20-24. In '8th Conference of the International Society for Plant Anaerobiosis, 20-24 September 2004. International Society for Plant Anaerobiosis. Perth, WA.

[25] Tekalign Mamo and Haque, I. (1991). Phosphorus status of some Ethiopian soils. Forms and Distribution of Inorganic Phosphates and Their Relation to Available Phosphorus. Trop. Agri. 68: 2-8.

[26] Tekalign Tadese (1991). Soil, plant, water, fertilizer, animal manure and compost analysis. Working Document No. 13. International Livestock Research Center for Africa, Addis Ababa.

[27] Toor, S. A. (1990). Effect of NPK application on the growth and yield of new maize genotype planted in two geometrical patterns. M. Sc. (Hons.) Agri. Thesis, Deptt. Agron. Univ. Agri., Faisalabad.

[28] Walkley, A. and Black, I. A (1934). An examination of the Digestion method for determining soil organic matter and a proposed modification of the chromic acid titration method. Journal Soil Science. 37: 29-38.

[29] Wichern, J., Wichern, F. and Joergensen. R. G (2006). Impact of salinity on soil microbial communities and decomposition of maize in acid soil, Geoderma 137: 100-108.

[30] Wondimagegne Chekol and Abere Mnalku. (2012). Selected Physical and Chemical Characteristics of Soils of the Middle Awash Irrigated Farm. Ethiopia Journal of Agriculture Science. 22: $127-142$

[31] Yacob Alemayehu (2015). Long-Term Impacts of Cultivation and Residue Burning Practices on Soil Carbon and Nitrogen Contents in Cambisols of Southwestern Ethiopia, American Journal of Agriculture and Forestry, 3 (3): 65-72. 